\title{
PENGARUH APLIKASI GEOGEBRA DALAM MENINGKATKAN KEMAMPUAN BERPIKIR KRITIS SISWA DI SMPN CIBINONG
}

\author{
Rezkiyana Hikmah \\ Program Studi Teknik Informatika, Universitas Indraprasta PGRI \\ Email: rezkiyana.hikmah2706@gmail.com
}

\begin{abstract}
Abstrak
Perkembangan media GeoGebra merupakan salah satu bentuk sumbangsih teknologi dalam dunia pendidikan, khususnya matematika. Penggunaan media GeoGebra dalam penelitian ini berkaitan dengan pembuatan garis dalam sebuah persamaan untuk mencari gradien. Penelitian ini bertujuan untuk melihat apakah kemampuan berpikir kritis siswa yang belajar dengan media GeoGebra lebih baik dari pembelajaran biasa dan apakah peningkatan kemampuan berpikir kritis siswa yang belajar dengan media GeoGebra lebih baik dari pada pembelajaran biasa. Sampel penelitian ini siswa kelas VIII tahun pelajaran 2019/2020 di SMPN 1 Cibinong. Sampel berjumlah 60 siswa. Jenis penelitian yang dilakukan adalah kuasi eksperimen dengan desain penelitian kelompok kontrol non ekivalen. Instrumen yang digunakan adalah pretes dan postes untuk melihat $n$-gain kemampuan berpikir kritis. Data penelitian dianalisis dengan uji Mann-Whitney. Hasil yang diperoleh adalah peningkatan kemampuan berpikir kritis siswa yang belajar dengan media GeoGebra lebih baik daripada siswa yang belajar dengan pembelajaran biasa.
\end{abstract}

Kata Kunci : Media Geogebra, Kemampuan Berpikir Kritis

\begin{abstract}
The development of GeoGebra media is a form of a technological contribution to the field of education, especially mathematics. The use of GeoGebra media in this study is related to making lines in an equation to find gradients. This study aims to see whether the critical thinking skills of students who learn with GeoGebra media are better than ordinary learning and whether the increase in critical thinking skills of students with GeoGebra media is better than ordinary learning. The sample of this study was class VIII in the School Year 2019/2020 at SMPN 1 Cibinong. The samples were 60 students. This type of research is a quasi-experimental research design with a non-equivalent control group. The instrument used were pretest and postest to see n-gain critical thinking skills. The research data were analyzed with the Mann-Whitney test. The result was the improvement of the critical thinking ability of students who learn with GeoGebra media better than students who learn with ordinary learning.
\end{abstract}

Key Words : GeoGebra media, Critical Thinking Skills

\section{PENDAHULUAN}

Matematika merupakan ilmu pasti yang menjadi salah satu ilmu dasar dalam setiap bidang teknologi. Peran matematika yang begitu besar menjadikan matematika sebagai salah satu mata pelajaran yang diikutsertakan dalam ujian nasional (UN). Hal tersebut semestinya menjadikan matematika sebagai mata pelajaran yang setiap siswanya dapat memenuhi standar kelulusan nilai UN. Namun kenyataannya, pentingnya matematika tidak membuat matematika menjadi mata pelajaran yang diminati dan disukai oleh siswa. Hal ini dikarenakan matematika merupakan mata pelajaran yang berkaitan dengan sesuatu yang abstrak, seperti variabel, persamaan, simbol, notasi dan sebagainya. Hal tersebut memicu para siswa kurang tertarik atau bahkan menghindar dari mata pelajaran matematika. Nilai matematika yang rendah diaanggap sebagai hal biasa oleh para siswa.

Rendahnya minat siswa dalam belajar matematika, mendorong para praktisi ilmu pendidikan mencari solusi dalam persoalan tersebut. Melalui perkembangan teknologi di bidang pendidikan, media pembelajaran yang berbasis teknologi informasipun 
banyak bermunculan sebagai jawaban dari persoalan tersebut. Media pembelajaran dalam matematika saat ini di antaranya cabri 2D, cabri 3D, wingeom, GeoGebra dan sebagainya. Media pembelajaran tersebut memiliki keunggulan masingmasing. Kebermanfaatannya dapat disesuaikan dengan kebutuhan pembelajaran di kelas.

Salah satu media pembelajaran yang dapat digunakan dalam beberapa materi matematika yaitu GeoGebra. GeoGebra merupakan software yang dirancang untuk membantu guru dalam menanamkan konsep materi melalui tampilan gambar dan visualisasi yang menarik. Hal tersebut senada dengan [1] yang menyatakan bahwa "pemahaman konsep matematika siswa akan lebih baik bila diajarkan dengan pembelajaran berbantuan media GeoGebra daripada pembelajaran konvensional (ekspositori)". Tampilan gambar yang dapat digerakkan secara manual atau otomatis, serta pemberian warna pada gambar dapat menarik minat siswa dalam belajar matematika. Hal yang abstrak dapat disajikan secara konkrit melalui media GeoGebra. Salah satu materi yang dapat disajikan dengan GeoGebra adalah persamaaan garis lurus dan gradien. Aplikasi dari penggunaan GeoGebra dapat dilihat pada Gambar 1 berikut.

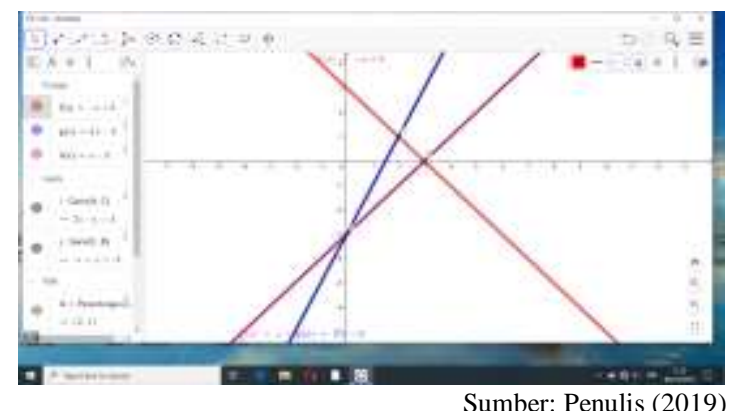

Gambar 1. Persamaan Garis Luru Dan Gradien Pada Aplikasi GeoGebra

Berdasarkan Gambar 1, guru dapat menuliskan persamaan di sisi lembar kiri software dan selanjutnya akan muncul garis pada lembar kerja di sebelah kanan software. Perhatikan di sisi kiri ada fungsi $f(x)=-x+3$ yang ditandai dengan warna bulatan merah. Selanjutnya perhatikan di sisi kanan ada garis yang berwarna merah dengan keterangan tulisan $f(x)=-x+3$. Hal tersebut memudahkan siswa untuk melihat ciri dari setiap garis yang tergambar di sisi kanan layar ketika guru menuliskan beberapa fungsi di sisi kiri layar. Selanjutnya, warna garis dan ketebalan garis dapat diatur pada sisi kanan atas layar sisi kanan, sehingga guru dapat menebalkan garis agar terlihat lebih jelas oleh siswa yang duduk di bagian belakang. Selain itu, pada software GeoGebra juga terdapat beberapa toolbar di pada kiri atas layar,sehingga dapat membantu guru dalam mendesain gambar untuk pembelajaran di kelas. Salah satu jenis toolbar tersebut adalah midpoint yang berguna untuk membuat poin dari perpotongan dua garis. Pada gambar 1, poin A merupakan perpotongan dari garis berwarna biru dan garis berwarna merah. Hal yang sama juga untuk poin B dan C. Dengan demikian siswa dapat melihat dengan jelas bagaimana proses pembuatan garis pada sisi kanan layar GeoGebra. Kemudian, yang paling penting adalah gambar yang didesain dapat dilihat secara jelas oleh semua siswa di kelas. Referensi [1] yang menyatakan bahwa "melalui GeoGebra, konsep abstrak pada geometri dapat divisualisasikan sehingga dalam mempelajari dan menganalisis konsep tersebut akan lebih mudah". Dengan demikian, siswa dapat memahami makna dari garis lurus dan gradien dengan melihat kemiringan garis atau berdasarkan persamaan garis dengan lebih mudah melalui media GeoGebra.

Hal tersebut dapat membantu siswa dalam memahami konsep materi dengan menyeluruh. Selain itu adanya pemberian warna pada garis atau gambar dan tulisan juga merupakan salah satu bentuk variasi 
penyajian materi agar lebih menarik minat siswa untuk mengetahui lebih lanjut materi tersebut. Kemampuan berpikir kritis akan muncul ketika siswa memiliki minat dalam belajar dan hal tersebut dapat ditunjang dengan menyajikan media yang menarik. Siswa dapat difasilitasi dengan menganalisa gradien dari gambar garis yang telah disajikan oleh guru. Selain itu, siswa dapat menghubungkan materi garis dengan materi sebelumnya. Misal perpotongan dari ketiga garis $\mathrm{A}, \mathrm{B}$ dan $\mathrm{C}$ tersebut ternyata membentuk bangun segitiga sembarang. Hal tersebut menunjukkan adanya kemampuan kritis yang muncul dari media yang disajikan dengan menarik kepada siswa. Oleh karena itu, penggunaan media GeoGebra diharapkan dapat memaksimalkan pembelajaran agar lebih efektif, efisien dan interaktif.

Dengan demikian, diharapkan kemampuan berpikir kritis matematis siswa dapat ditingkatkan melalui media pembelajaran GeoGebra. Referensi [2] menyatakan bahwa "kemampuan berpikir kritis adalah aspek kunci dari pembelajaran, salah satu tujuan pengajaran yang penting adalah membantu siswa memahami konsep utama dan dalam suatu subjek bukan hanya mengingat fakta-fakta yang terpisahpisah". Referensi [3] yang menyatakan bahwa "Adanya gambar statis walaupun sederhana, ternyata dapat membantu mahasiswa dalam menyusun atau merumuskan langkah-langkah pembuktian". Berdasarkan pendapat tersebut, mahasiswa dapat terbantu dalam menyusun tersebut merupakan salah satu bentuk berpikir kritis. Oleh karena itu, pembelajaran matematika melalui media GeoGebra dapat membantu siswa dalam berpikir kritis. Referensi [4] menyatakan bahwa "Bantuan ICT seperti software Geogebra juga dapat menarik minat mahasiswa terhadap pembelajaran matematika".
Penelitian ini bertujuan untuk mengetahui apakah kemampuan berpikir kritis siswa dengan menggunakan media pembelajaran GeoGebra lebih baik daripada siswa yang pembelajarannya dilakukan secara konvensional dan untuk mengetahui apakah peningkatan kemampuan berpikir kritis siswa dengan menggunakan media pembelajaran GeoGebra lebih baik daripada siswa yang pembelajarannya dilakukan secara konvensional. Adapun manfaat dari penelitian ini bagi siswa dan guru di antaranya adalah (1) memberikan pengalaman dan wawasan baru bagi guru dalam menggunakan media pembelajaran yang variatif dan interaktif, yaitu media GeoGebra; (2) membantu guru menambah skill (kemampuan) dalam menerapkan media pembelajaran yang variatif dan interaktif dalam pembelajaran, yaitu media GeoGebra; dan (3) membantu guru dalama menperoleh informasi mengenai minat siswa terhadap penggunaan media GeoGebra.

Media GeoGebra merupakan sebuah aplikasi komputer yang menampilkan fiturfitur visualisasi bidang geometri. Referensi [4] menyatakan bahwa "penggunaan software Geogebra dapat membantu para pendidik dan anak didik dalam proses belajar". Pembelajaran matematika yang berkaitan dengan gambar akan sangat lebih menarik jika dijelaskan menggunakan media GeoGebra. Hal tersebut dikarenakan media GeoGebra memiliki fasilitas dalam mendesain gambar agar lebih menarik dengan warna dan animasi. Geogebra adalah salah satu cara yang efektif dalam mengkomunikasikan konsep yang abstrak menjadi konsep yang konkrit. Oleh karena itu, materi tersebut dapat dengan mudah dipahami oleh siswa. Referensi [5] menyatakan bahwa "geogebra dapat dimanfaatkan sebagai media pembelajaran matematika untuk mendemonstrasikan atau memvisualisasikan konsep-konsep matematika". 
Menurut Lavicza sejumlah penelitian menunjukkan bahwa GeoGebra dapat mendorong proses penemuan dan eksperimentasi siswa di kelas. Fitur-fitur visualisasinya dapat secara efektif membantu siswa dalam mengajukan berbagai konjektur matematis. Beberapa pemanfaatan program GeoGebra dalam pembelajaran matematika adalah sebagai berikut.

a. Dapat menghasilkan lukisan-lukisan geometri dengan cepat dan teliti dibandingkan dengan menggunakan pensil, penggaris, atau jangka.

b. Adanya fasilitas animasi dan gerakangerakan manipulasi (dragging) pada program GeoGebra dapat memberikan pengalaman visual yang lebih jelas kepada siswa dalam memahami konsep geometri.

c. Dapat dimanfaatkan sebagai balikan/evaluasi untuk memastikan bahwa lukisan yang telah dibuat benar.

d. Mempermudah guru/siswa untuk menyelidiki atau menunjukkan sifatsifat yang berlaku pada suatu objek geometri.

Menurut Hohenwarter \& Fuchs GeoGebra sangat bermanfaat sebagai media pembelajaran matematika dengan beragam aktivitas sebagai berikut.

a. Sebagai media demonstrasi dan visualisasi

Dalam hal ini, dalam pembelajaran yang bersifat tradisional, guru memanfaatkan GeoGebra untuk mendemonstrasikan dan memvisualisasikan konsep-konsep matematika tertentu.

b. Sebagai alat bantu konstruksi

Dalam hal ini GeoGebra digunakan untuk memvisualisasikan konstruksi konsep matematika tertentu, misalnya mengkonstruksi lingkaran dalam maupun lingkaran luar segitiga, atau garis singgung.

c. Sebagai alat bantu proses penemuan
Dalam hal ini GeoGebra digunakan sebagai alat bantu bagi siswa untuk menemukan suatu konsep matematis, misalnya tempat kedudukan titik-titik atau karakteristik parabola.

Kemampuan berpikir kritis adalah aspek kunci dari pembelajaran, salah satu tujuan pengajaran yang penting adalah membantu siswa memahami konsep utama dan dalam suatu subjek bukan hanya mengingat faktafakta yang terpisah-pisah [2]. Tujuan dari dilaksanakan pembelajaran adalah bukan untuk menghafalkan materi atau rumus. Namun, lebih dari itu siswa dibimbing dalam pembelajaran untuk dapat memahami materi dan konsep utama materi. Hal tersebut dimaksud agar siswa mampu menalar dan menganalisis setiap persoalan dalam keseharian dengan lebih tajam. Mampu mengambil keputusan dalam setiap situasi persoalan yang dihadapi. Pada akhirnya, siswa dapat berpikir lebih kritis dalam menghadapi setiap situasi keadaaan dan persoalan yang ada di sekitarnya. Hal tersebut sejalan dengan pendapat [4] "sering kali mahasiswa salah langkah dalam mengambil berbagai keputusan dengan tidak memahami konsep yang sebenarnya dan tidak diiringi dengan berpikir kritis".

Berpikir kritis adalah proses yang melibatkan operasi mental seperti induksi, deduksi, klasifikasi, dan penalaran [3]. Dengan berpikir kritis, orang menjadi memahami argumentasi berdasarkan perbedaan nilai, memahami adanya inferensi dan mampu menginterpretasi, mampu mengenali kesalahan, mampu menggunakan bahasa dalam berargumen, menyadari dan mengendalikan egosentris dan emosi, dan responsif terhadap pandangan yang berbeda [3]. Berdasarkan kedua pendapat tersebut dapat disimpulkan bahwa seseorang dapat bersikap lebih bijak dan berpikir lebih rasional ketika orang tersebut mampu memahami persoalan dan 
situasi dengan lebih jelas melalui tingkat pemahaman dan analisis terhadap suatu persoalan yang disertai dengan berpikir kritis. Selain itu, orang tersebut juga mampu mengkomunikasikan apa yang dianalisis dengan bahasa yang dapat dipahami serta mampu menyimpulkan inti dari suatu persoalan. Hal yang sama juga dalam pembelajaran, siswa dapat lebih bijak dan rasional dalam memahami penyelesaian soal dan materi berdasarkan tingkat pemahaman dan analisis soal.

Dengan adanya kegiatan memanipulasi gambar secara dinamis secara tidak langsung akan dapat mengasah kemampuan mahasiswa dalam menyusun pembuktian [3]. Melalui pembelajaran GeoGebra, siswa dapat memahami pembuktian dalam memperoleh rumus pada materi gradien tanpa harus menghafalkan rumus. Pembelajaran dapat dilaksanakan dengan lebih bermakna karena siswa dibimbing dalam memahami konsep materi gambar geometri dari media yang dilihat dan siswa mampu mengumpulkan pengetahuan dalam pembuktian rumus dan pemahaman konsep. Proses pembelajaran berbantu geoGebra dapat juga dikombinasi dengan penggunaan LKS. Hal tersebut dapat membantu meningkatkan kemampuan siswa dalam berpikir kritis. Hal tersebut sesuai dengan hasil penelitian dari pendapat [3], "Penerapan perangkat pembelajaran LKM multi representasi berbantuan Geogebra pada perkuliahan geometri bidang dapat meningkatkan kemampuan berpikir kritis mahasiswa".

\section{Tabel 1. Indikator Soal Kemampuan}

\section{Berpikir Kritis}

\begin{tabular}{|c|c|}
\hline No & Indikator Soal Berpikir Kritis \\
\hline \multirow{3}{*}{1} & $\begin{array}{l}\text { Mengidentifikasi sifat }- \text { sifat suatu konsep } \\
\text { (Pemahaman }\end{array}$ \\
\hline & Mengidentifikasi \\
\hline & $\begin{array}{l}\text { karakteristik tertentu melalui sajian titik - } \\
\text { titik koordinat (kemampuan berpikir kritis. }\end{array}$ \\
\hline 2 & Mengidentifikasi persamaan garis dengan \\
\hline
\end{tabular}

\begin{tabular}{lllr}
\hline \multicolumn{3}{l}{ karakteristik tertentu. } \\
Mengidentifikasi posisi & $\begin{array}{l}\text { garis dengan } \\
\text { melalui } \\
\text { pajakteristik tertentu } \\
\text { persamaan aljabar. }\end{array}$ & \\
\hline & & Sumber: Rohaeti [6]
\end{tabular}

\section{METODE}

Penelitian ini dilakukan di SMP Negeri 1 Cibinong pada Bulan Oktober 2019 sampai dengan Januari 2020. Sekolah ini beralamat di Jl. Raya Mayor Oking Jaya Atmaja No.60 A, Ciriung, Cibinong, Bogor, Jawa Barat 16918. Sampel pada penelitian ini yaitu siswa kelas VIII yang terdaftar pada semester gasal tahun akademik 2019/2020 diambil dengan metode simple random sampling.

Penelitian yang termasuk ke dalam penelitian kuantitatif ini, menggunakan metode penelitian korelasional. Metode ini bertujuan untuk meneliti sejauh mana variasi-variasi pada suatu faktor berkaitan dengan variasi-variasi faktor lain berdasarkan koefisien korelasi. Pada penelitian ini terdapat kelas eksperimen dan kelas kontrol. Pada kelas eksperimen, diterapkan pembelajaran dengan menggunakan media GeoGebra. Sementara di kelas kontrol diterapkan metode pembelajaran yang sama, hanya tanpa menggunakan media GeoGebra. Penelitian ini didesain sebagai berikut.

Tabel 2. Desain Penelitian

\begin{tabular}{lcc}
\hline & $\begin{array}{c}\text { Pembelajaran } \\
\text { dengan } \\
\text { Media } \\
\text { GeoGebra } \\
\text { (A1) }\end{array}$ & $\begin{array}{c}\text { Pembelajaran } \\
\text { tanpa media } \\
\text { GeoGebra } \\
\text { (A2) }\end{array}$ \\
\hline $\begin{array}{l}\text { Berpikir } \\
\text { kritis (B1) }\end{array}$ & A1B1 & A2B1 \\
\hline & & Sumber : Penulis (2019)
\end{tabular}

Keterangan :

A1B1: Kemampuan berpikir kritis dengan pembelajaran menggunakan media Geogebra

A2B1: Kemampuan berpikir kritis dengan pembelajaran tanpa menggunakan media Geogebra 
Desain pelaksanaan penelitian untuk menguji pemahaman matematis dan kemampuan berpikir kritis kelompok eksperimen dan kontrol pretes-postes sebagai berikut :

\begin{tabular}{llll}
\hline A1 & 0 & $\mathrm{X}$ & 0 \\
$\mathrm{~A} 2$ & 0 & & 0 \\
\hline
\end{tabular}

Keterangan :

A1 $=$ Kelas Eksperimen.

A2 = Kelas Kontrol

$\mathrm{O}=$ Pretes - Postes

$\mathrm{X}=$ Perlakuan berupa pembelajaran dengan media GeoGebra.

Populasi pada penelitian ini adalah seluruh siswa Kelas VIII yang terdaftar di SMP Negeri 1 Cibinong, yang terdaftar di semester ganjil tahun akademik 2019/2020. Sampel yang terpilih adalah siswa Kelas VIIID (sebagai kelas eksperimen) dan kelas VIIIB (sebagai kelas kontrol).

Instrumen penelitian meliputi soal pretes dan postes kemampuan pemahaman dan kemampuan berpikir kritis matematis serta angket minat belajar. Instrument pretes dan postes yang digunakan adalah sama. Hal ini untuk mengukur peningkatan kemampuan pemahaman dan berpikir kritis matematis siswa. Instrumen tes dan angket yang digunakan diadopsi dari tes dan angket yang sudah terstandarisasi. Hal ini dilakukan untuk mengefektifkan waktu penelitian. Adapun kisi-kisi untuk instrumen tes ini adalah sebagai berikut.

Tabel 3. Indikator dan Soal Kemampuan Berpikir Kritis

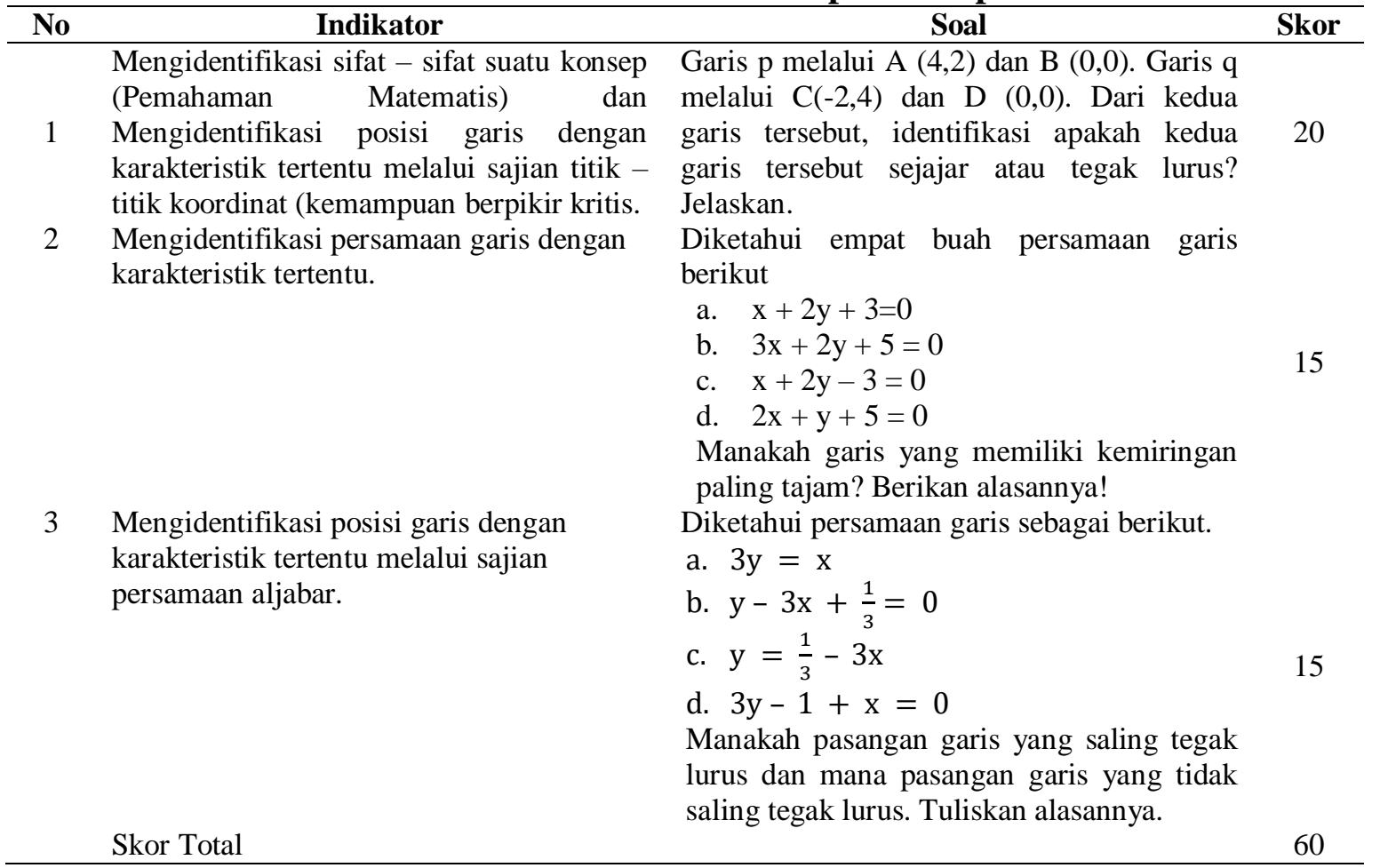

HASIL DAN PEMBAHASAN

Hipotesis tersebut akan diuji kebenarannya dengan rumusan hipotesis untuk satu pihak adalah
$H_{o}: \mu_{1}=\mu_{2}$ Kemampuan berpikir kritis matematis siswa yang belajar dengan GeoGebra tidak lebih baik daripada 
siswa yang belajar dengan pembelajaran biasa.

$\mathrm{H}_{1}: \mu_{1}>\mu_{2} \quad$ Kemampuan berpikir kritis matematis siswa yang belajar dengan GeoGebra lebih baik daripada siswa yang belajar dengan pembelajaran biasa.

$\mathrm{H}_{\mathrm{o}}: \mu_{1}=\mu_{2}$ Peningkatan kemampuan berpikir kritis matematis siswa yang belajar dengan GeoGebra tidak lebih baik daripada siswa yang belajar dengan pembelajaran biasa.

$\mathrm{H}_{1}: \mu_{1}>\mu_{2} \quad$ Peningkatan kemampuan berpikir kritis matematis siswa yang belajar dengan GeoGebra lebih baik daripada siswa yang belajar pembelajaran biasa.

dengan

Hipotesis tersebut diuji dengan kriteria pengujian antara siswa yang belajar dengan GeoGebra di kelas eksperimen dan siswa yang belajar dengan pembelajaran biasa di kelas kontrol. Jika sig (1-tailed) $\geq \alpha=0,05$ maka terima $\mathrm{H}_{\mathrm{o}}$ dan jika sig (1-tailed) $<\alpha$ $=0,05$ maka tolak $\mathrm{H}_{\mathrm{o}}$.

Pengujian hipotesis dilakukan dengan uji non parametrik dengan uji Mann-Whitney dengan taraf signifikansi $\alpha=0,05$. Jika sig (1-tailed) $\geq \alpha$ maka $\mathrm{H}_{\mathrm{o}}$ diterima dan sebaliknya jika sig (1-tailed) $<\alpha$ maka $\mathrm{H}_{\mathrm{o}}$ ditolak. Hasil uji perbedaan dua rerata postes dan N-Gain kemampuan berpikir kritis matematis siswa dapat dilihat pada Tabel 4 berikut.

Tabel 4. Hasil Uji Perbedaan Dua Rerata Postes dan N-Gain Kemampuan Berpikir Kritis Matematis Siswa

\begin{tabular}{cccccc}
\hline \multirow{2}{*}{ Skor } & $\begin{array}{c}\text { Mann- } \\
\text { Whitney } U\end{array}$ & $\mathbf{Z}$ & $\begin{array}{c}\text { Asymp. Sig. (2- } \\
\text { tailed) }\end{array}$ & $\begin{array}{c}\text { Asymp. Sig. } \\
\text { (1-tailed) }\end{array}$ & Ket \\
\hline Postes & 302,500 & $-0,252$ & 0,801 & 0,4005 & Terima $\mathrm{H}_{\mathrm{o}}$ \\
N-Gain & 222,500 & $-1,947$ & 0,052 & 0,026 & Tolak $\mathrm{H}_{\mathrm{o}}$ \\
\hline & & & & & Sumber: Penulis (2019)
\end{tabular}

Berdasarkan Tabel 4, dapat dilihat bahwa data nilai postes dan n-gain dilakukan dengan uji Mann-Whitney karena data postes dan n-gain tidak berdistribusi normal. Kriteria pengujian dengan uji Mann-Whitney dengan $\alpha=0,05$ adalah jika sig (1-tailed) $\geq \alpha$ maka $\mathrm{H}_{\mathrm{o}}$ diterima. Nilai signifikansi satu pihak pada nilai postes kemampuan berpikir kritis matematis lebih tinggi dari nilai $\alpha=0,05$ yaitu 0,4005 maka $\mathrm{H}_{\mathrm{o}}$ diterima. Hal tersebut dapat diartikan bahwa kemampuan berpikir kritis matematis siswa yang belajar dengan GeoGebra tidak lebih baik daripada siswa yang belajar dengan pembelajaran biasa.

Selanjutnya nilai signifikansi satu pihak pada nilai n-gain kemampuan berpikir kritis matematis lebih rendah dari nilai $\alpha=$
0,05 yaitu 0,026 maka $\mathrm{H}_{\mathrm{o}}$ ditolak. Hal tersebut dapat diartikan bahwa peningkatan kemampuan berpikir kritis matematis siswa yang belajar dengan GeoGebra lebih baik daripada siswa yang belajar dengan pembelajaran biasa. Peningkatan kemampuan berpikir kritis siswa yang terjadi dengan kategori peningkatan yang rendah.

Pada pertemuan pertama, pembelajaran matematika dengan pembelajaran media GeoGebra diawali dengan menyampaikan memberikan motivasi, dan menyampaikan model pembelajaran yang akan digunakan yaitu menggunakan media GeoGebra. Guru membagi siswa ke dalam lima kelompok yang terdiri dari 5 orang. Setiap kelompok diminta untuk berdiskusi 
kelompok. Setiap kelompok bertanggung jawab untuk menjawab pertanyaan dari guru yang berkaitan dengan bangun ruang yang didapat. Selanjutnya guru mempersiapakan media yang akan digunakan selama pembelajaran. Guru memberikan contoh gradien yang dapat dilihat dalam keseharian seperti kemiringan lantai pada kolam renang, posisi tangan saat hormat bendera dan tangga yang disandarkan pada dinding. Guru menyampaikan permasalahan seputar gradien secara umum yang disajikan dalam media GeoGebra. Misalnya guru membuat sebuah persamaan dan meminta siswa untuk menggambar garis gradien dari persamaan tersebut dan menentukan berapa gradien garis tersebut. Misal persamaan $2 \mathrm{x}+\mathrm{y}=2$ seperti pada Gambar 4.3 berikut.

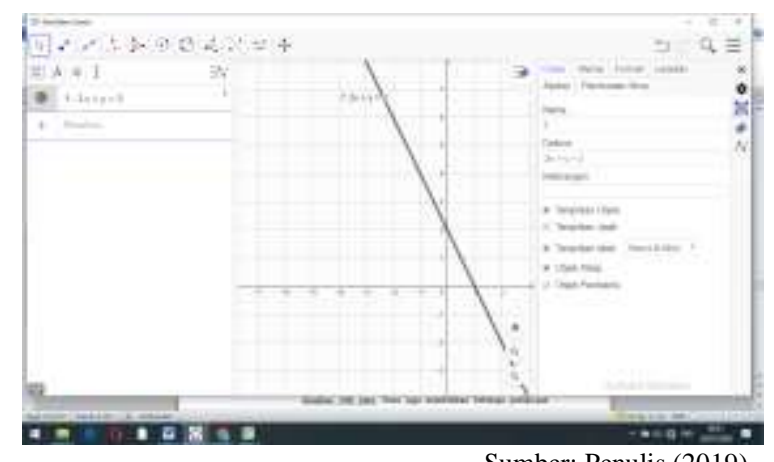

Gambar 2. Contoh Bentuk Pertanyaan Mengenai Gradien

Guru menggunakan media GeoGebra pada saat menjelaskan gambar dan berapa gradien dari persamaan $2 x+y=2$. Melalui media GeoGebra, guru menuliskan persamaan di lembar kerja bagian kiri dan secara langsung garis dari persamaan tersebut akan terbentuk. Selanjutnya guru juga menjelaskan bagaimana cara memperoleh gambar garis tersebut tanpa media GeoGebra. Guru mengerjakannya dengan cara memisalkan nilai $\mathrm{x}=0$ untuk memperoleh nilai y. Selanjutnya memisalkan nilai $\mathrm{y}=0$ untuk memperoleh nilai $x$, sehingga akan diperoleh dua titik koordinat. Jika masih kurang, maka guru dapat memisalkan nilai $\mathrm{x}$ dan $\mathrm{y}$ dengan nilai selain 0 untuk memperoleh 2 titik koordinat berikutnya. Dengan demikian akan diperoleh gambar garis dari persamaan tersebut.

Pada saat presentasi dari guru mengenai gradien, siswapun diajak untuk menjawab dari pertanyaan yang sesekali dilontarkan oleh guru pada saat menjelaskan materi. Guru juga meminta siswa untuk mengulangi penjelasan dari apa yang telah disampaikan. Siswa mencoba memprediksi jawaban dari pertanyaan sambil memperhatikan media GeoGebra yang disajikan oleh guru. Proses pembelajaran dengan media GeoGebra membuat siswa termotivasi untuk belajar dan menganalisa gambar dan gradien dari persamaan yang diberikan oleh guru. Dengan demikian, pembelajaran dengan media GeoGebra dapat mengkonstruksi pemahaman awal siswa mengenai gradien.

Setelah guru menyampaikan konsep gradien melalui media GeoGebra, guru meminta siswa untuk menyelesaikan soal yang ada pada buku paket secara berkelompok. Setiap kelompok berdiskusi dalam menyelesaikan soal tersebut dengan menuliskan hasil jawabannya di dalam catatan masing-masing siswa. Diskusi kelompok berlangsung lebih kurang 45 menit.

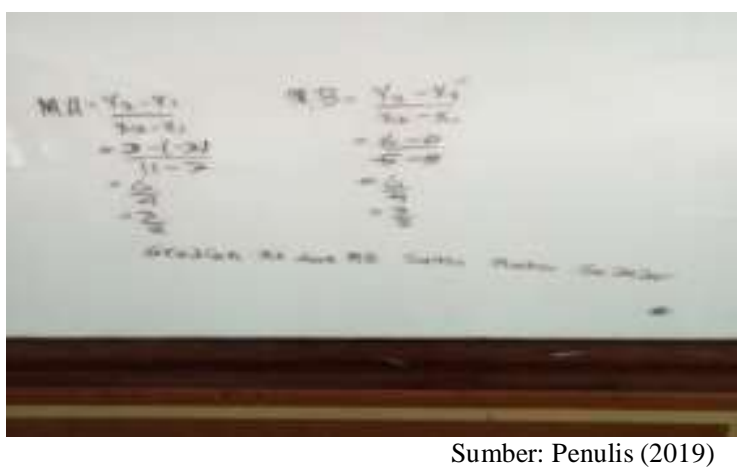

Gambar 3. Hasil Jawaban Siswa dari Salah Satu Kelompok 
Selanjutnya, guru meminta tiap kelompok mengutus perwakilannya untuk membahas satu soal yang ditulis di papan tulis. Setiap kelompok menjelaskan setiap jawaban soal yang telah dituliskan di papan tulis. Selanjutnya, kelompok lain akan menanggapi atau bertanya untuk sesuatu hal yang masih dirasa bingung. Setelah pembahasan soal, guru memberikan kuis kepada siswa untuk dikerjakan secara individu. Di akhir pembelajaran, guru menyampaikan materi yang akan dibahas pada pertemuan selanjutnya.

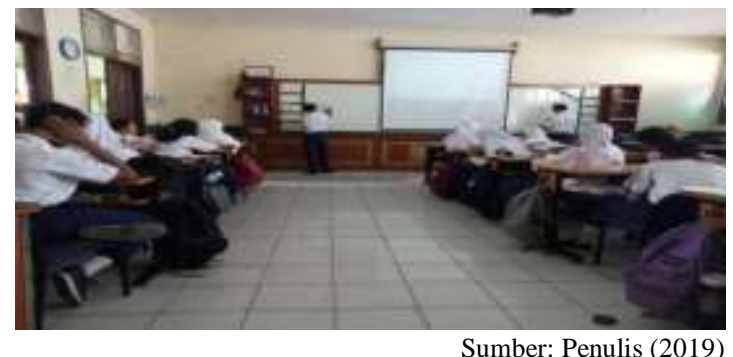

\section{Gambar 4. Proses Pembelajaran di Kelas Eksperimen}

Berdasarkan hasil penelitian yang diperoleh, terlihat bahwa media pembelajaran GeoGebra tidak memiliki pengaruh terhadap kemampuan berpikir kritis siswa secara signifikan. Namun, bila ditilik pada jalannya pelaksanaan penelitian, terdapat beberapa variabel pengganggu yang kemungkinan besar mempengaruhi hasil penelitian. Beberapa di antaranya adalah pertama, waktu penelitian. Beberapa pertemuan saat penelitian di kelas eksperimen sempat mengalami kendala. Kendala pertama adalah saat pertemuan kedua penelitian. Saat itu, jadwal yang seharusnya digunakan untuk masuk di materi kedua, harus terjeda karena jadwalnya bertabrakan dengan jadwal persiapan guru untuk persiapan kegiatan outdoor sekolah yang akan diadakan esok harinya. Akibatnya, saat itu, guru hanya memberikan materi dan meminta siswa untuk mempelajari materi tersebut secara mandiri. Kendala kedua adalah saat pertemuan keempat.
Pertemuan keempat kembali mengalami pemunduran jadwal. Hal ini dikarenakan pada saat pertemuan keempat di kelas eksperimen, guru tidak mengajar dikarenakan sakit. Akibatnya, pada saat itu, siswa kembali diminta untuk belajar sendiri.

Kendala ketiga adalah tiadanya review materi di kelas eksperimen seperti yang dilakukan di kelas kontrol. Akibat pertemuan keempat yang mengalami kemunduran, pertemuan yang dijadwalkan untuk review materi akhirnya tergantikan oleh pertemuan keempat. Kendala keempat adalah saat pelaksanaan tes. Pada saat akan pengambilan data berupa tes dan pengisian angket di kelas eksperimen, siswa masih sedang melakukan kegiatan gotong royong membersihkan kelas. Akibatnya, waktu pelaksanaan tes menjadi berkurang. Kondisi badan siswa yang lelah ditambah waktu pelaksanaan tes yang berkurang, kemungkinan mempengaruhi hasil penelitian ini.

\section{SIMPULAN}

Berdasarkan uraian dan penjelasan pada hasil penelitian dan pembahasan sebelumnya, simpulan penelitian yang dapat dikemukakan adalah.

1. kemampuan berpikir kritis matematis siswa yang belajar dengan media GeoGebra tidak lebih baik daripada siswa yang belajar dengan pembelajaran biasa.

2. Peningkatan kemampuan berpikir kritis matematis siswa yang belajar dengan media GeoGebra lebih baik daripada siswa yang belajar dengan pembelajaran biasa.

\section{DAFTAR PUSTAKA}

[1] S. Jelatu, Sariyasa2, dan I. M. Ardana. "Pengaruh Penggunaan Media GeoGebra terhadap Pemahaman Konsep Geometri Ditinjau dari Kemampuan Spasial 
Siswa”. J. Pendidik. dan Kebud. Missio, vol. 10, no. 2, pp. 162-171, 2018.

[2] H. Irawati. "Pengaruh Pembelajaran Penemuan Terbimbing terhadap Kemampuan Pemahaman Matematik Siswa", in Prosiding Seminar Nasional Pendidikan Matematika Program Pasca Sarjana STKIP Siliwangi Bandung, vol. 1, p. 208, 2014.

[3] I. P. W. Ariawan. "Pengembangan LKM Multi Representasi Berbantuan GeoGebra untuk Meningkatkan Kemampuan Berpikir Kritis Mahasiswa". J. Pendidik. Indones., vol. 3, no. 1, pp. 359-371, 2014.

[4] I. H. Batubara. "Peningkatan
Kemampuan Berpikir Kritis Mahasiswa melalui Metode Penemuan Terbimbing Berbantu Software GeoGebra pada Mata Kuliah Kalkulus Peubah Banyak di FKIP UMSU". MES (Journal Math. Educ. Sci., vol. 4, no. 2, pp. 152-159, 2019.

[5] D. R. Asngari. "Penggunaan Geogebra dalam Pembelajaran Geometri”. in Prosiding Seminar Nasional Matematika dan Pendidikan Matematika, 2015.

[6] H. Hendriana, E. E. Rohaeti, dan U. Sumarmo. Hard Skills dan Soft Skills Matematik Siswa. Kedua. Cimahi: PT Refika Aditama, 2018. 